\title{
Pengaruh Penggunaan Serat Rotan Terhadap Stabilitas Dan Durabilitas Untuk Bahan Tambah Campuran Lataston
}

\author{
Juinto Siada Putra*1, Risal Alfin Inrinto*2, Monika. D. M. Palinggii ${ }^{*}$, Rais Rachman ${ }^{* 4}$ \\ *1,2 Mahasiswa Prodi Teknik Sipil, Universitas Kristen Indonesia Paulus, Makassar, Indonesia \\ intoxsiada@gmail.com , alfinrisalinrianto@gmail.com \\ *3,4 Dosen Prodi Teknik Sipil, Universitas Kristen Indonesia Paulus, Makassar, Indonesia \\ Rais.Rachman@gmail.com,monika.datu@gmail.com
}

\begin{abstract}
ABSTRAK
Salah satu perkerasan jalan yang sering digunakan di Indonesia yaitu campuran Lataston. Dalam penelitian ini dilakukan pengujian terhadap karakteristik campuran Lataston HRS-WC dan HRS-BASE dengan memanfaatkan serat rotan sebagai bahan tambah. Hasil penelitian menunjukkan bahwa karakteristik bahan perkerasan dengan penambahan serat rotan memenuhi spasifikasi sebagai bahan lapisan perkerasan jalan. Hasil uji Marshall diperoleh karakteristik campuran Lataston HRS-WC dengan kadar serat rotan 10\% mendapatkan Indeks Perendaman (IP) / Indeks Kekuatan Sisa (IKS) / durabilitas sebesar $94,77 \%$ dan Lataston HRS-BASE dengan kadar serat rotan $10 \%$ mendapatkan Indeks Perendaman (IP) / Indeks Kekuatan Sisa (IKS) / Durabilitas sebesar $92,48 \%$.
\end{abstract}

Kata Kunci : Lataston HRS-WC; HRS-BASE; Serat Rotan; Karakteristik Marshall Konvesional; Marshall immertion.

\begin{abstract}
One of the pavements that is often used in Indonesia is the Lataston mixture. In this study, the characteristics of the mixture of Lataston HRS-WC and HRS-BASE were tested by using rattan fiber as an added ingredient. The results of research showed that the characteristics of the pavement material with the addition of rattan fiber met the spasification as a pavement coating material. Marshall test results obtained mixture characteristics of Lataston HRS-WC with $10 \%$ rattan fiber content get Immersion Index (IP) / Residual Strength Index (IKS) / durability of $94.77 \%$ and HRS-BASE Lataston with $10 \%$ rattan fiber content get Immersion Index (IP) / Time Strength Index (IKS) / Durability of $92.48 \%$.
\end{abstract}

Keywords: : Lataston HRS-WC; HRS-BASE; rattan fiber; Marshall conventional characteristics; Marshall immertion. 


\section{PENDAHULUAN}

Pesatnya pembangunan prasarana jalan mengakibatkan meningkatnya kebutuhan bahanbahan yang digunakan, termasuk pemakaian agregat. Untuk memenuhi kebutuhan tersebut diperlukan sumber daya alam yang harus dimanfaatkan seoptimal mungkin, mengingat semakin banyak agregat yang digunakan sebagai lapisan perkerasan jalan.

Lapis tipis aspal beton (lataston) adalah penutup yang terdiri dari campuran agregat bergradasi senjang dan semi senjang, filler dan aspal keras dengan perbandingan tertentu; yang yang dicampur dan dipadatkan secara panas (suhu tertentu, minimum $124^{\circ} \mathrm{C}$ ), dengan ketebalan padat $2,5 \mathrm{~cm}$ atau $3 \mathrm{~cm}$. Konstruksi perkerasan HRS dalam penggunaannya dibagi menjadi dua kelas yaitu kelas A (Wearing Course) dan kelas B (Base Course). Perbedaan kedua konstruksi perkerasan tersebut terdapat pada gradasi agregat yang digunakan, beban lalu lintas dan segi pemakaian. Jenis agregat yang digunakan terdiri dari agregat kasar, agregat halus dan butiran pengisi (filler), sedangkan aspal yang digunakan biasanya jenis aspal keras AC 60-70 dan AC 80-100.

Campuran lapis tipis aspal beton biasanya terdiri atas aspal yang digunakan sebagai bahan pengikat, agregat kasar dan halus sebagai bahan utama dan filler sebagai pengisi. Untuk HRS-WC dan HRS-Base, paling sedikit $80 \%$ agregat lolos ayakan No.8 $(2,36 \mathrm{~mm})$ harus juga lolos ayakan No.30 $(0,600 \mathrm{~mm})$. Kriteria gradasi senjang yang lolos ayakan No.8 $(2,36 \mathrm{~mm})$ dan tertahan ayakan No.30 $(0,600 \mathrm{~mm})$ [1].

Seiring dengan berkembangnya teknologi, banyak penelitian yang dilakukan untuk memaksimalkan stabilitas dan durabilitas campuran beraspal. Salah satunya dengan penambahan bahan tambah seperti serat dalam campuran beraspal. Penambahan bahan serat dapat meningkatkan ketahanan campuran beraspal terhadap tekanan beban lalulintas.

Tujuan penelitian adalah untuk mengetahui karakteristik aspal dan agregat dan mengetahui pengaruh penambahan serat rotan terhadap stabilitas dan durabilitas campuran lataston.

\section{Metode Rancangan Campuran HRS - WC (Mix Design HRS)}

Metode rancangan campuran HRS yang digunakan adalah rancangan campuran aspal panas (Hot Mix) yaitu suatu campuran yang terdiri dari komponen-komponen agregat yang merupakan komponen terbesar dalam campuran dan bahan pengikatnya aspal dimana cara pencampurannya melalui proses pemanasan. Perencanaan campuran HRS-WC yang digunakan berdasarkan metode Marshall, dengan metode ini kita dapat menentukan jumlah pemakaian aspal yang tepat sehingga dapat menghasilkan komposisi yang baik antara agregat dengan aspal sesuai dengan persyaratan teknis jalan yang ditentukan.

Komposisi rancangan campuran didasarkan pada gradasi campuran agregat yang dipilih. Komposisi rancangan campuran agregat dibagi atas tiga fraksi yaitu : fraksi agregat kasar, fraksi agregat halus, fraksi bahan pengisi. Stabilitas adalah kemampuan perkerasan jalan menerima beban lalu lintas tanpa terjadi perubahan bentuk, tetap seperti gelombang, alur dan bleeding. Stabilitas terbentuk akibat adanya gesekan internal dan gaya ikatan aspal yang ada di dalam campuran. Untuk memperoleh stabilitas yang tinggi sebaiknya digunakan agregat yang memiliki gradasi rapat, permukaan kasar dan bentuk seperti kubus, serta menggunakan aspal berpenetrasi rendah dalam jumlah yang cukup. Kestabilan yang terlalu tinggi akan menyebabkan lapisan perkerasan menjadi kaku dan cepat mengalami retak. Hal ini terjadi karena volume antara agregat kurang, sehingga menghasilkan film aspal yang tipis dan bisa menyebabkan ikatan aspal mudah lepas. Pada akhirnya hal tersebut akan menyebabkan lapisan tidak kedap air dan oksidasi mudah terjadi, sehingga lapisan perkerasan menjadi rusak. Pengukuran stabilitas dilakukan melalui pengujian di laboratorium yang dinamakan dengan Marshall Test.

\section{Durabilitas}

Durabilitas (keawetan) adalah kemampuan lapisan permukaan untuk menerima repetisi beban lalu lintas seperti berat kendaraan, gesekan antara roda kendaraan dengan permukaan jalan, serta menahan keausan akibat pengaruh cuaca dan iklim seperti udara, air atau perubahan temperatur. Durabilitas lapisan dipengaruhi oleh tebalnya film atau selimut aspal, banyaknya pori dalam campuran, kepadatan dan kedap airnya campuran. Selimut aspal yang cukup akan membungkus aspal secara baik, sehingga lapisan akan kedap air serta lebih mampu menahan keausan. Besarnya pori yang tersisa dalam campuran setelah pemadatan akan mengakibatkan durabilitas lapisan menurun. Salah satu cara untuk melihat potensi durabilitas campuran adalah dengan melihat nilai indeks kekuatan sisa (IKS) yang didapatkan sebagai hasil dari tes perendaman marshall. Semakin tinggi nilai IKS menyatakan potensi durabilitas dari campuran tersebut semakin baik. 


\section{Agregat}

Agregat adalah suatu bahan keras dan kaku yang digunakan sebagai bahan campuran yang berupa butiran atau pecahan, yang termasuk didalamnya antara lain pasir, kerikil, agregat pecah, dan abu agregat.

\section{Bahan Pengisi (Filler)}

Bahan pengisi atau filler merupakan agregat yang lebih halus di bandingkan agregat halus umumnya yang lolos saringan No. 200. Filler adalah bahan yang berfungsi mengurangi rongga,dan menambah kekuatan tarik pada campuran beton aspal.

Pembuatan lapis permukaan dari beton aspal diperlukan agregat dengan gradasi tertentu, untuk itu biasanya dibutuhkan disamping agregat kasar, agregat halus, juga pengisi/filler.

Bahan pengisi yang ditambahkan harus kering dan bebas dari gumpalan-gumpalan dan bila diuji dengan pengayakan harus mengandung bahan yang lolos ayakan No.200 (75 micron) tidak kurang dari 75\% terhadap beratnya kecuali untuk mineral Asbuton. Mineral Asbuton harus mengandung bahan yang lolos ayakan No.100 (150 micron) tidak kurang dari 95\% terhadap beratnya.

\section{Semen (Portland)}

Semen biasa disebut juga Portland Cement (PC). Semen adalah suatu bahan pengikat hidrolis yang dapat mengeras jika dicampur dengan air. Dalam penggunaan semen harus disesuaikan dengan kondisi lingkungan artinya sesuai dengan jenisnya.

\section{Rotan}

Rotan berasal dari bahasa melayu yang berarti nama dari sekumpulan jenis tanaman family palmae yang tumbuh memanjat yang di sebut Lepidocarlyodidae ( Yunan = mencakup ukuran buah). Indonesia memenuhi $80 \%$ rotan di dunia(terbesar).

Secara umum komposis kimia rotan terdiri dari holoselulosa (71-76\%), selulosa (39\%-56\%). Liknin (18\%-27\%), silicia (0,54\%-8\%). Sifat fisik rotan adalah sifat-sifat yang dapat diamati secara kasat mata seperti warna, kilap, bau, rasa, berat, kekerasan/elastisitas, diameter luas dan lain-lain. Sifat struktur dari rotan belum di ketahui karena belum penelitian khusu terhadap sifat-sifat struktur tersebut yang dapa digunakan sebai petunjuk indentivikasi adalah pori. Pori rotan sangat sederhana dan di bedakan dalam beberapa bagian antara lain ukuran bentuk dan susunan. Sifat mekanis rotan berkaitan dengan kemampuan menahan gaya dari luar, antara lain: keteguhan tekan, patah, kekakuan, keuleta, keteguhan tarik, geser, belah dan keawetannya.

\section{Pengujian Marshall}

a. Konvensional

Kinerja campuran HRS dapat diperiksa dengan alat pemeriksaan Marshall.Pemeriksaan ini pertama kali dikenalkan oleh Bruce Marshall, selanjutnya dikembangkan oleh U.S. Corps of EngineerAlat Marshall merupakan alat tekan yang dilengkapi dengan proving ring (cincin penguji) yang berkapasitas $2500 \mathrm{~kg}$ atau 5000 pound. Proving ring dilengkapi dengan arloji pengukur yang berguna untuk mengukur stabilitas campuran, di samping itu terdapat arloji kelelehan (flow meter)untuk mengukur kelelehan plastis (flow). Pengujian Marshall (Marshall Test) adalah suatu metode pengujian untuk mengetahui nilai ketahanan (stabilitas) dan kelelehan plastis (flow) campuran beraspal.Ketahanan adalah kemampuan menerima beban sampai terjadi kelelehan plastis, dinyatakan dalam satuan kilogram atau pound. Dengan kata lain stabilitas Marshall dimaksudkan sebagai beban maksimum yang dapat diterima oleh campuran sebelum runtuh. Sedangkan kelelehan plastis adalah perubahan bentuk campuran aspal yang terjadi akibat suatu beban hingga batas runtuh, yang dinyatakan dalam mm.Sebelum pengujian Marshall terlebih dahulu dilakukan proses perendaman benda uji. Proses perendaman benda uji dilakukan pada suhu $60^{\circ} \mathrm{C}$ selama $30-45$ menit dan 24 jam dan melakukan pengujian Marshall untuk mengetahui sifat mekanik benda uji yaitu stabilitas dan flow.

\section{b. Pemeriksaan Marshall Immertion}

Maksud dari pemeriksaan ini adalah untuk membandingkan nilai stabilitas antara campuran yang dipanaskan selama 30 menit dengan nilai stabilitas campuran HRS yang direndam selam 24 jam dengan suhu $60^{\circ} \mathrm{C}$. Nilai perbandingan harus memenuhi standar yang ditetapkan oleh Bina Marga yaitu lebih besar dari $75 \%$.

\section{Daktilitas}

Daktilitas aspal adalah nilai keelastisitasan aspal, yang diukur dari jarak terpanjang, apabila antara dua cetakan berisi bitumen keras yang ditarik sebelum putus pada suhu $25^{\circ} \mathrm{C}$ dan dengan kecepatan 50 $\mathrm{mm} / \mathrm{menit}$. Metode ini dimaksudkan sebagai acuan dan pegangan dalam pelaksanaan pengujian daktilitas bahan aspal. Tujuan metode ini adalah untuk mendapatkan harga pengujian daktilitas bahan aspal.

\section{Kehilangan Berat}

Maksud pengujian untuk mengetahui kehilangan minyak pada aspal akibat pemanasan yang berulang 
dan pengujian ini juga bertujuan untuk mengukur perubahan kinerja aspal akibat kehilangan berat.

\section{Pemeriksaan Agregat Kasar}

a. Analisa Saringan

Untuk menentukan pembagian butiran terhadap agregat kasar.

Pemeriksaan Kekuatan Agregat Terhadap Tumbukan (Aggregate impact value/AIV).

Pengujian kekuatan agregat terhadap tumbukan adalah proses dasar pada pembuatan agregat dimana seberapa besar kehancuran agregat setelah tumbukan (Aggregat Impact Value).

\section{b. Pemeriksaan Keausan dengan Alat Abrasi Los Angeles}

Pengujian ini adalah untuk mengetahui angka keausan tersebut, yang dinyatakan dengan perbandingan antara berat bahan aus lolos saringan No. $12(1,7 \mathrm{~mm})$ terhadap berat semula, dalam persen.

\section{c. Pemeriksaan Berat Jenis dan Penyerapan Agregat Kasar}

Tujuan pengujian ini untuk memperoleh angka berat jenis curah, berat jenis kering permukaan jenis dan berat jenis semu serta besarnya angka penyerapan.

\section{d. Pengujian Kelekatan Agregat Terhadap Aspal}

Pengujian ini dapat dilakukan terhadap semua jenis bahan yang digunakan sebagai agregat bahan jalan dan campuran aspal. Hasil pengujian ini selanjutnya dapat digunakan dalam pengendalian mutu agregat pada pembangunan jalan.

\section{e. Pemeriksaan Indeks Partikel Pipih dan Lonjong}

Pengujian ini bertujuan untuk menguji keseragaman agregat, agar memperluas perencanaan dan pelaksanaan pekerjaan pada proyek.

\section{Pemeriksaan Agregat Halus}

a. Analisa Saringan

Untuk menentukan pembagian butiran terhadap agregat halus.

b. Pemeriksaan Berat Jenis dan Penyerapan Agregat Halus

Tujuan pengujian ini untuk memperoleh angka berat jenis curah, berat jenis kering permukaan jenis dan berat jenis semu serta besarnya angka penyerapan.

C. Pemeriksaan Kadar Lumpur Agregat Halus
(Pasir)
Metode pengujian agregat halus atau pasir yang mengandung bahan plastis (bahan yang mengandung lempung atau lanau) .

\section{d. Material Lolos Saringan No.200}

Untuk memperoleh persentase jumlah bahan agregat yang berguna bagi perncanaan dan pelaksanaan pembangunan jalan.

\section{Penelitian Sebelumnya}

Penelitian yang dilakukan dengan memanfaatkan serat serabut kelapa dan filler serbuk bentonit untuk memberikan variasi additive dan filler dalam campuran perkerasan lentur Dimana penggunaan serat serabut kelapa dapat meningkatkan kualitas perkerasan Hot Rolled Asphalt (HRA). Berdasarkan data tersebut dilakukan penelitian dengan mengaplikasikan kedua bahan tersebut untuk mengetahui pengaruhnya terhadap HRS-Base dan HRSWC.

Hasil penelitian menunjukkan bahwa penggunaan serat serabut kelapa sebagai bahan tambah dan filler serbuk bentonit pada HRS-Base hanya memenuhi syarat pada variasi 1 (bentonit:abu batu=4:0) dan variasi 4 (1:3) dengan kadar aspal 9\%, serta variasi 3 dengan kadar aspal $9 \%$ dan $10 \%$. Pada HRS-WC tidak ada yang memenuhi syarat, sehingga tidak direkomendasikan untuk digunakan pada HRS-WC. [2].

Penelitian penggunaan limbah las karbit untuk bahan tambah pada perkerasan laston gradasi AC-WC dengan hasil dari paramter Marshall didapat kadar aspal optimum untuk $0 \%$ sebesar $6,6 \%$, aspal karbit $2,5 \%$ didapat $6,7 \%$, dan untuk aspal karbit $5 \%$ sebesar $6,8 \%$ [3].

Pada pengujian studi karakteristik Marshall pada campuran aspal dengan penambahan limbah botol plastik menghasilkan semakin tinggi kadar penambahan Polyethylene Terephthalate mengakibatkan peningkatan stabilitas dan nilai kadar rongga dalam campuran.

Penggunaan bahan additive wetfixbe sebagai bahan tambah pada lapis permukaan AC-WC menghasilkan kadar aspal optimum sebesar $6,2 \%$ pada permukaan lapis permukaan AC-WC aspal pen 60/70. Pemakaian untuk bahan additive anti striping wetfixbe dengan dosis 0,25\% mengakibatkan peningkatan nilai stabilitas, kepadatan VFB dan MQ [4].

Penggunaan abu batu bara hasil pembakaran asphalt mixing plant sebagai bahan campuran laston dengan hasil stabilitas pada penambahan abu batu bara $2 \%$ adalah $1.875,18 \mathrm{~kg}$, durabilitas pada 
penambahan abu batu bara 3\% adalah 152,05\%, untuk campuran AC-BC stabilitas pada penambahan abu batu bara $2 \%$ adalah $1.875,18 \mathrm{~kg}$ dan durabilitas pada penambahan 3-4\% adalah 152,05\% [5].

Penelitian durabilitas pada campuran AC-BC menggunakan limbah kerak tanur cangkang kelapa sawit menghasilkan pemakaian kadar yang tinggi untuk limbah tanur cangkang kelapa sawit akan meningkan nilai stabilitas dan menurunkan nilai flow dan density [6].

Pengujian pengaruh bahan tambah limbah cor pada AC-WC terhadap karakteristik Marshall dengan hasil penambahan paling mendekati efektif adalah pada kadar 9\%, karena pada saat itu nilai stabilitas marshall mengalami kenaikan yang sangat tinggi yaitu dari $1753,47 \mathrm{~kg}$ menjadi $2355,26 \mathrm{~kg}$. Sedangkan untuk nilai kepadatannya sebesar VIM 4,97\%, VMA 16,47\%, VFA $72,61 \%$, flow 3,18 mm serta MQ 1158,32 kg/mm [7].

\section{METODOLOGI PENELITIAN}

Langkah kerja penelitian dimulai dengan pemeriksaan sifat fisik bahan, penelitian menggunakan aspal minyak dengan penetrasi 60/70 dengan menambahkan variasi serat rotan $0 \%, 2 \%$, $4 \%, 6 \%$, $8 \%$, dan $10 \%$, pembuatan benda uji, pengujian karakteristik Marshall Konvensional dan Marshall Immersion, dan dilanjutkan dengan analisis. Bagan alir penelitian dapat dilihat pada Gambar 3.

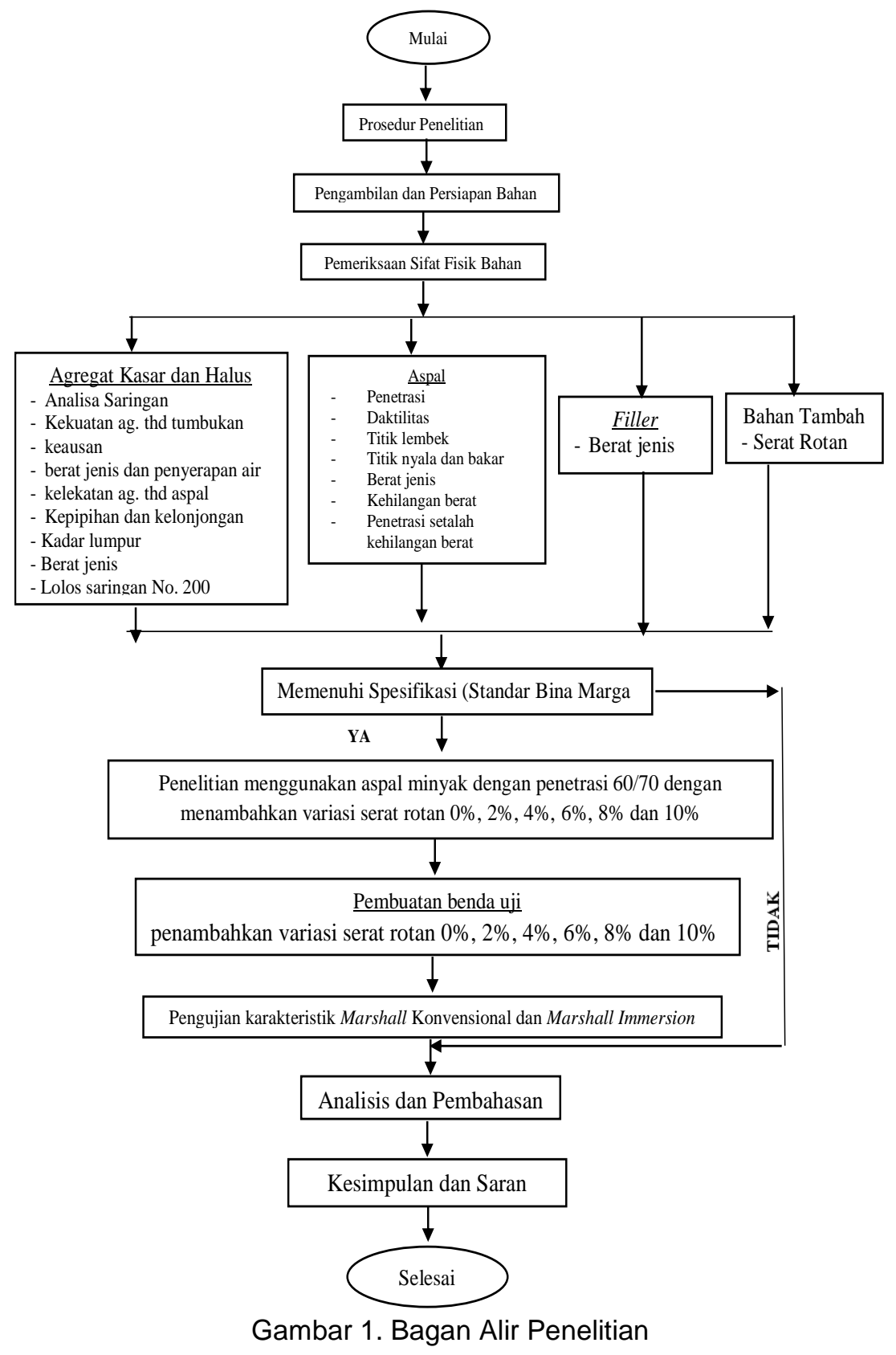




\section{HASIL DAN PEMBAHASAN}

\section{Data dan Analisis Karakteristik Agregat}

Berdasarkan hasil pengujian karakteristik agregat batu Sungai Jeneberang Kecamatan Bili-bili Kabupaten Gowa Provinsi Sulawesi Selatan dan karakteristik filler semen.

\section{a. Keausan Agregat}

Dari hasil pengujian keausan agregat dengan menggunakan Alat Abrasi Los Angeles diperoleh nilai ketahanan agregat kasar terhadap keausan dari Fraksi A adalah $28.22 \%$, Fraksi B adalah $24.64 \%$, Fraksi C adalah $18.28 \%$ dan Fraksi D adalah $19.20 \%$. Dari semua hasil pengujian, tiap fraksi memenuhi standar dengan nilai maksimum $40 \%$. Sehingga, dapat diketahui bahwa agregat yang digunakan sebagai bahan lapisan permukaan jalan dapat tahan terhadap keausan akibat gesekan antara agregat dengan agregat atau agregat dengan roda kendaraan.

\section{b. Berat Jenis dan Penyerapan Agregat Kasar}

Berdasarkan hasil pengujian berat jenis dan penyerapan agregat kasar yang menggunakan dua sampel diperoleh nilai untuk Berat Jenis Bulk adalah $2.675 \%$ berat jenis SSD adalah $2.700 \%$, berat jenis semu adalah $2.742 \%$ dan Penyerapan Air adalah $0.903 \%$. Semua hasil pengujian memenuhi Spesifikasi Umum yaitu untuk Berat Jenis Bulk, Berat Jenis SSD dan Berat Jenis Semu adalah minimal 2.5\% dan Penyerapan Air maksimal 3\% atau dapat dikatakan bahwa penyerapan agregatnya kecil.

\section{c. Berat Jenis dan Penyerapan Agregat Halus}

Nilai rata-rata untuk berat benis bulk adalah 2,601\%, Berat Jenis SSD adalah 2,660\%, Berat jenis semu adalah 2,764 \% dan Penyerapan air adalah 2,251\%.

\section{d. Berat Jenis Filler}

Berdasarkan hasil pengujian berat jenis filler semen $100 \%$ dapat ditarik kesimpulan bahwa nilai berat jenis filler yang diperoleh sebesar $3,02 \mathrm{gr} / \mathrm{cm}^{3}$. Dengan demikian filler tersebut telah memenuhi standar yang ditetapkan dan dapat digunakan dalam campuran beraspal.

\section{e. Hasil Pengujian Uji Material Lolos Saringan 200}

Hasil pengujian material lolos saringan 200, diperoleh nilai sebesar $4.28 \%$ sedangkan maksimum yang menjadi ketentuan dari Spesifikasi Umum adalah sebesar $8 \%$ Dengan demikian agregat yang digunakan agregat.

\section{f. Hasil Pengujian Kadar Lumpur}

Hasil pengujian kadar lumpur dengan menggunakan dua sampel diperoleh hasil rata-rata untuk nilai Sand Equivalen adalah 96,25 \% dan kadar lumpur 3,02\%.

g. Hasil Pengujian Indeks Kepipihan dan Kelonjongan

Hasil indeks kepipihan dan kelonjongan ini dapat diketahui bahwa agregat kasar diperoleh indeks kepipihan $9.20 \%, \quad 8.68 \%, \quad 7.59 \%$ dan indeks kelonjongan yaitu $7.34 \%, 6.19 \%, 5.85 \%$. Nilai dari indeks kepipihan dan kelonjongan telah memenuhi Standar Bina Marga yaitu maksimal 10\% sehingga dapat disimpulkan bahwa pecahan batu sungai dari Bili-bili bebentuk kubus (bidang pecah lebih dari 1).

\section{h. Hasil Pengujian Kelekatan Agregat Terhadap Aspal}

Pengujian kelekatan aspal ini hanya bersifat visualisasi yang tidak melalui proses perhitungan. Nilai kelekatan ditentukan dari luas permukaan sampel yang terselimuti aspal (kurang dari $95 \%$ atau lebih dari $95 \%$ ). Dari pengamatan ini dapat diketahui bahwa aspal dapat melekat dengan baik pada agregat dengan nilai kelekatan $>95 \%$.

\section{i. Karakteristik Aspal}

Data karakteristik aspal adalah data sekunder yang diperoleh dari pengujian sebelumnya. Hasil pengujian karakteristik aspal penetrasi $60 / 70$ adalah sebagai berikut:

Hasil Pengujian Penetrasi Sebelum Kehilangan Berat. Dari hasil pengujian aspal yang telah dilakukan, didapatkan data nilai penetrasi adalah 65.7. Dari data tersebut dapat disimpulkan bahwa aspal yng digunakan tergolong dalam aspal yang keras. Karena aspal pada suhu ruang nilai penetrasinya 65.7.

Hasil Pengujian Titik Lembek. Dari hasil pengujian titik lembek aspal didapatkan nilai rata-rata $48^{\circ} \mathrm{C}$. Hasil ini masuk dalam syarat yang ditentukan dalam dalam SNI 06-2434-1991 yaitu $48-58^{\circ} \mathrm{C}$.

Hasil Pengujian Titik Nyala. Dari hasil pengujian daktilitas didapatkan nilai rata-rata untuk titik nyala 300 dan titik bakar 300 .

Hasil Pengujian Kehilangan Berat. Dari hasil pengujian penurunan berat aspal didapatkan nilai rata-rata 0,020 .

Hasil Pengujian Penetrasi Sesudah Kehilangan Berat. Setelah melakukan penelitian sesuai prosedur pelaksanaan, hasil yang diperoleh adalah $64,4 \%$ semula dimana nilianya lebih besar dari standar spesifikasi umum.

Hasil Pengujian Daktilitas. Dari hasil pengujian daktilitas didapatkan nilai rata-rata 121 . 
Hasil Pengujian Berat Jenis. Dari hasil pengujian daktilitas didapatkan nilai rata-rata 1,047.

\section{Analisis Terhadap VIM}

Dengan menggunakan Serat Rotan 0\% - 10\% untuk Lataston HRS-WC diperoleh nilai VIM antara $4.13 \%$ - 5,00\%. Semakin besar penggunaaan Serat Rotan maka semakin besar juga nilai VIM. Hal ini disebabkan oleh banyaknya penggunaan serat rotan sehingga aspal akan menyelimuti permukaan serat rotan dan sedikit yang mengisi rongga dalam campuran.

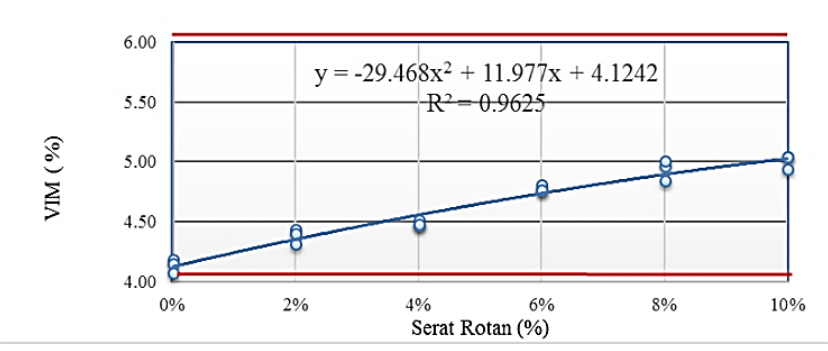

Gambar 2. Grafik hubungan VIM dan serat rotan untuk lataston HRS-WC.

Dengan menggunakan Serat Rotan 0\% - 10\% untuk Lataston HRS-BASE diperoleh nilai VIM antara 5,34 $\%-5,75 \%$. Nilai VIM dengan serat rotan 0\% - 10\% untuk Lataton HRS-BASE memenuhi persyaratan [9]. Semakin besar penggunaaan Serat Rotan maka semakin besar juga nilai VIM. Hal ini disebabkan oleh banyaknya penggunaan serat rotan sehingga aspal akan menyelimuti permukaan serat rotan dan sedikit yang mengisi rongga dalam campuran.

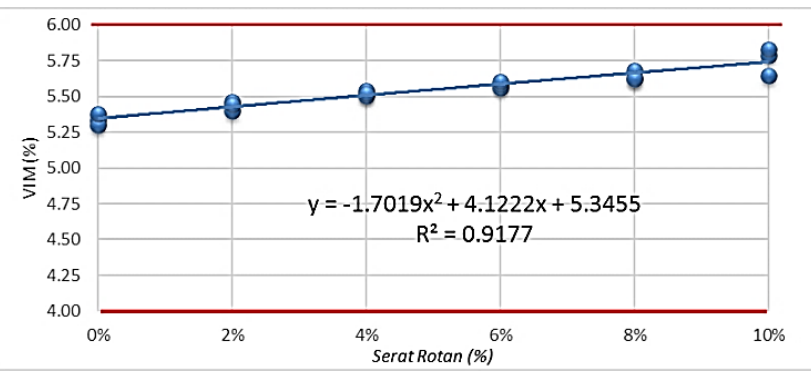

Gambar 3. Grafik hubungan VIM dan serat rotan untuk lataston HRS-BASE

\section{Analisis Terhadap Stabilitas}

Dengan menggunakan serat rotan $0 \%-10 \%$ untuk Lataston HRS-WC diperoleh nilai Stabilitas antara 1477,18- 1590,02 untuk Lataston HRS-WC dapat di lihat semua kadar aspal memenuhi persyaratan [9]. Serat rotan akan membantu meningkatkan kekuataan/stabilitas campuran lastaston pada 6\% serat rotan. Sedangkan pada campuran $8 \%-10 \%$ serat rotan kekuatan/stabilitasnya akan berkurang karena aspal akan banyak melapisi serat rotan sehingga mengakibatkan berkurangnya ikatan antar agregat sehingga menurunkan kekuatan/stabilitas campuran. ditunjukan dengan persamaan garis $\mathrm{y}=$ $10546 x^{2}+11373 x=1476,3$ maka di peroleh kenaikan stabilitasnya sebesar rata-rata $200,03 \mathrm{~kg}$ sampai serat rotan $4 \%$ dan akan menurun stabilitasnya sebesar rata-rata $95,74 \mathrm{~kg}$ jika semakin banyak serat rotan ditambahkan. Berdasarkan nilai korelasi $\mathrm{R}^{2=}$ 0,7305 maka terdapat pengaruh yang besar penambahan serat rotan terhadap stabilitas campuran. Hubungan stabilitas dan serat rotan untuk Lataston HRS - WC dapat dilihat pada Gambar 4.

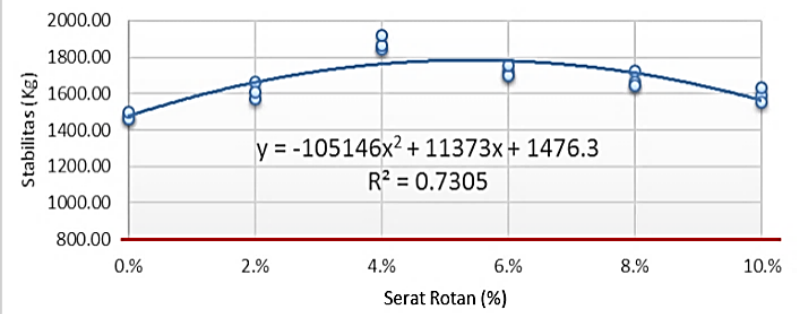

Gambar 4. Grafik hubungan stabilitas dan serat rotan untuk Lataston HRS-WC

Dengan menggunakan serat rotan $0 \%-10 \%$ untuk Lataston HRS-BASE diperoleh nilai stabilitas antara 1514,11-1391,01 untuk Lataston HRS-BASE dapat di lihat semua kadar aspal memenuhi persyaratan [9]. Penggunaan serat rotan akan membantu meningkatkan kekuataan/stabilitas campuran lastaston pada 6\% serat rotan. Sedangkan pada campuran $8 \%-10 \%$ serat rotan kekuatan/stabilitasnya akan berkurang karena aspal akan banyak melapisi serat rotan sehingga mengakibatkan berkurangnya ikatan antar agregat sehingga menurunkan kekuatan/stabilitas campuran.

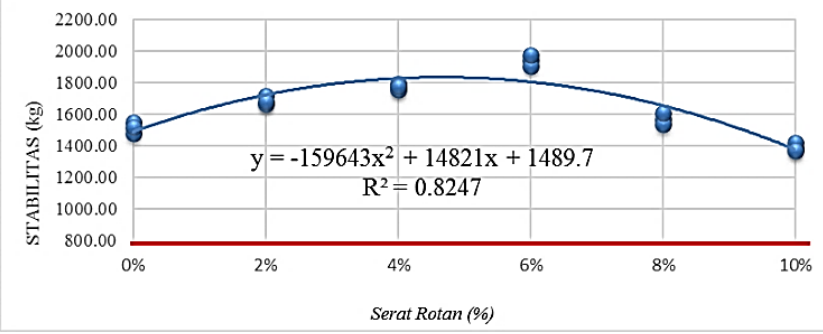

Gambar 5. Grafik hubungan stabilitas dan serat rotan untuk Lataston HRS-BASE.

\section{Analisis Terhadap Flow}

Dengan menggunakan serat rotan $0 \%-10 \%$ untuk Lataston HRS-WC diperoleh nilai Flow antara 3,23 5,42 . Dari Gambar 6 hubungan flow dengan serat rotan dapat disimpulkan bahwa dengan penembahan serat rotan yang lentur maka dapat meningkatkan flow dan kelenturan dalam campuran sehingga campurn menjadi lebih lentur. 


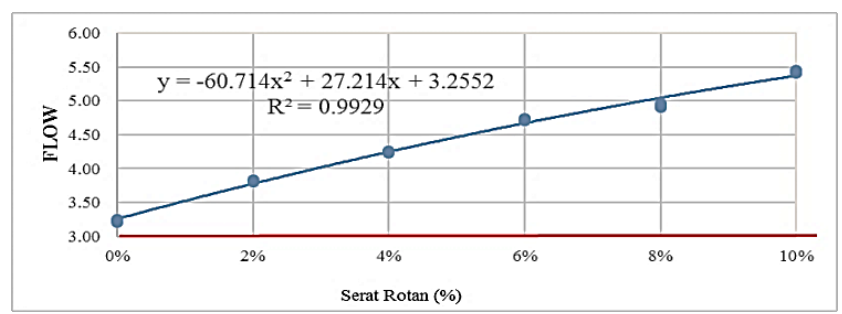

Gambar 6. Grafik hubungan flow dan serat rotan untuk Lataston HRS-WC

Dengan menggunakan serat rotan $0 \%-10 \%$ untuk Lataston HRS-BASE diperoleh nilai flow antara 3,22 - 4,52. Dari Gambar 7 hubungan flow dengan serat rotan dapat disimpulkan bahwa dengan penembahan serat rotan yang lentur maka dapat meningkatkan flow dan kelenturan dalam campuran sehingga campuran menjadi lebih lentur.

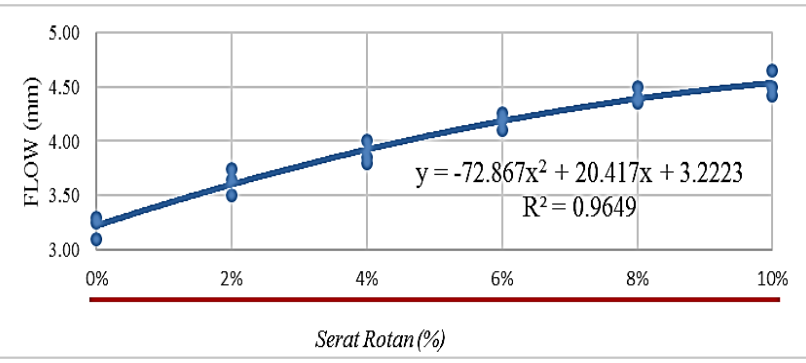

Gambar 7. Grafik hubungan flow dan serat rotan untuk Lataston HRS- BASE

\section{Analisis Terhadap VMA (Void in Mineral Aggregate)}

Dengan menggunakan Serat Rotan 0\% - 10\% untuk Lataston HRS-WC diperoleh nilai VMA antara 18,09 - 18,84. Nilai VMA dengan Serat rotan 0\% - 10\% untuk Lataston HRS-WC memenuhi persyaratan yang sudah di tetapkan yaitu Min 18. Dari Gambar 8 diketahui bahwa nilai VMA mengalami peningkatan, semakin besar penggunaaan Serat rotan maka semakin besar juga nilai VMA. Hal ini disebabkan banyaknya aspal yang menyelimuti agregat, filler dan serat rotan serta rongga dalam campuran sehingga rongga dalam agregat yang tidak terisi aspal semakin besar. ditunjukan dengan persamaan y $=-25,176 x^{2}$ $+10,233 x+18,088$ maka diperoleh peningkatan VMA sebesar rata-rata $0,15 \%$, sehingga setiap penambahan serat rotan sebagai bahan tambah pada lataston akan meningkatkan VMA. Berdasarkan nilai korelasi $\mathrm{R}^{2}=0,9625$ maka terdapat pengaruh yang besar penambahan serat rotan dengan stabilitas campuran.

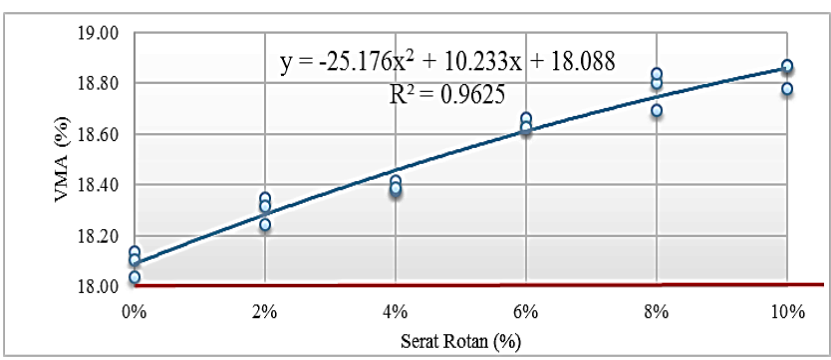

Gambar 8. Grafik hubungan VMA dan serat rotan untuk Lataston HRS - WC

Dengan menggunakan Serat Rotan 0\% - 10\% untuk Lataston HRS-BASE diperoleh nilai VMA antara 18,09 - 18,45. Dari Gambar 9 diketahui bahwa nilai VMA mengalami peningkatan, semakin besar penggunaaan Serat rotan maka semakin besar juga nilai VMA. Hal ini disebabkan banyaknya aspal yang menyelimuti agregat, filler dan serat rotan serta rongga dalam campuran sehingga rongga dalam agregat yang tidak terisi aspal semakin besar.

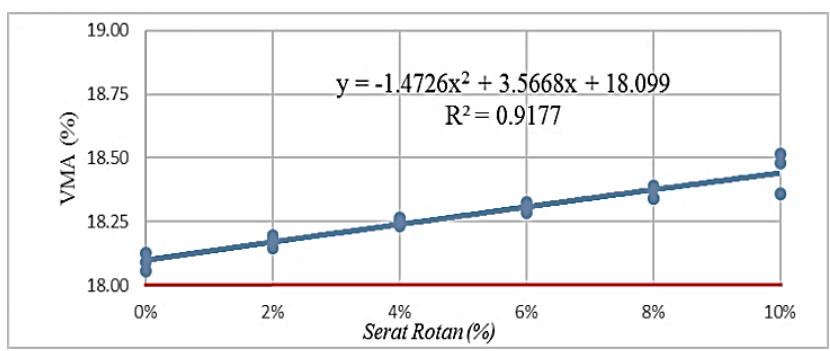

Gambar 9. Grafik hubungan VMA dan serat rotan untuk Lataston HRS - BASE

\section{Analisis Terhadap VFB (Void Filled Bitumen)}

Dengan menggunakan nilai Serat Rotan 0\% - 10\% untuk Lataston HRS-WC diperoleh nilai VFB antara 77,18 - 73,45. Penggunaaan Serat Rotan memenuhi VFB yang sudah di tetapkan. Setiap penambahan Serat rotan maka semakin banyak rongga udara yang terisi dan kekedapan campuran terhadap air dan udara akan semakin rendah. Nilai VFB yang terlalu rendah akan menyebabkan kekedapan campuran terhadap air berkurang karena sidikit rongga yang terisi aspal. Dengan banyaknya rongga yang kosong, air dan udara akan mudah masuk ke dalam lapisan keras sehingga keawetan dari lapisan keras akan berkurang.

Dengan menggunakan serat ijuk $0 \%-2 \%$ untuk Laston AC-WC diperoleh nilai Stabilitas antara 1126,35 - 1458,71 untuk Laston AC-WC. Berdasarkan Gambar 10 dapat disimpulkan bahwa penggunaan serat ijuk akan membantu meningkatkan kekuataan/stabilitas campuran laston AC-WC pada $1 \%$ serat ijuk. Sedangkan pada campuran 1,5\%-2\% serat ijuk kekuatan/stabilitasnya akan berkurang karena aspal akan banyak melapisi serat ijuk sehingga mengakibatkan berkurangnya 
ikatan antar agregat sehingga menurunkan kekuatan/stabilitas campuran, persamaan garis $\mathrm{y}=$ $139,7 x^{2}-52,462 x+77,194$ maka diperoleh VFB sebesar rata-rata $0,75 \%$, sehingga dengan penggunaan penambahan serat rotan sebagai bahan tambah pada lataston dapat menurunkan VFB. Berdasarkan nilai korelasi $\mathrm{R}^{2}=0,9632$ maka terdapat pengaruh yang besar penambahan serat rotan dengan stabilitas campuran.

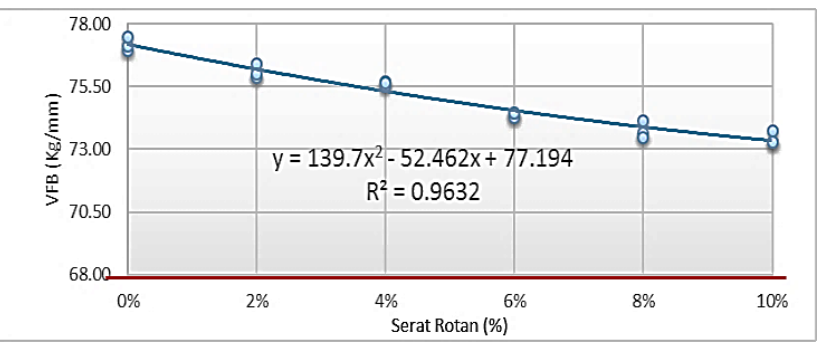

Gambar 10. Grafik hubungan VFB dan serat rotan Lataston HRS-WC

Dengan menggunakan nilai Serat Rotan 0\% - 10\% untuk Lataston HRS-BASE diperoleh nilai VFB antara 70,49 - 68,83. Penggunaaan Serat Rotan memenuhi VFB yang sudah di tetapkan. Setiap penambahan Serat rotan maka semakin banyak rongga udara yang terisi dan kekedapan campuran terhadap air dan udara akan semakin rendah. Nilai VFB yang terlalu rendah akan menyebabkan kekedapan campuran terhadap air berkurang karena sidikit rongga yang terisi aspal. Dengan banyaknya rongga yang kosong, air dan udara akan mudah masuk ke dalam lapisan keras sehingga keawetan dari lapisan keras akan berkurang.

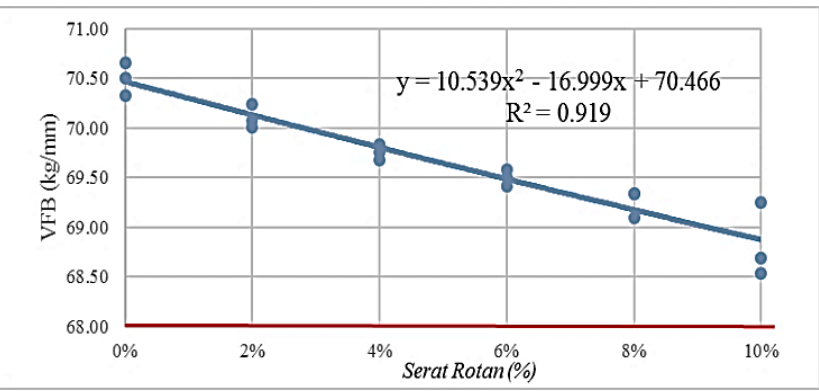

Gambar 11. Grafik hubungan VFB dan serat rotan Lataston HRS-BASE

\section{Penentuan Serat Rotan Untuk Lataston HRS- WC}

Penentuan proporsi serat rotan dapat ditentukan serat rotan yang optimum dalam campuran Lataston HRS-WC yaitu campuran yang memenuhi semua kriteria atau karakteristik marshall campuran mulai dari Serat rotan 0\% - 10\% untuk lataston HRS-WC. Karena menggunakan serat rotan terbanyak, juga dengan stabilitas paing kecil sehingga jika campuran masih tahan terhadap perendaman, apalagi campuran lainnya yang stabilitasnya besar. Grafik penentuan serat rotan dapat dilihat pada Gambar 12.

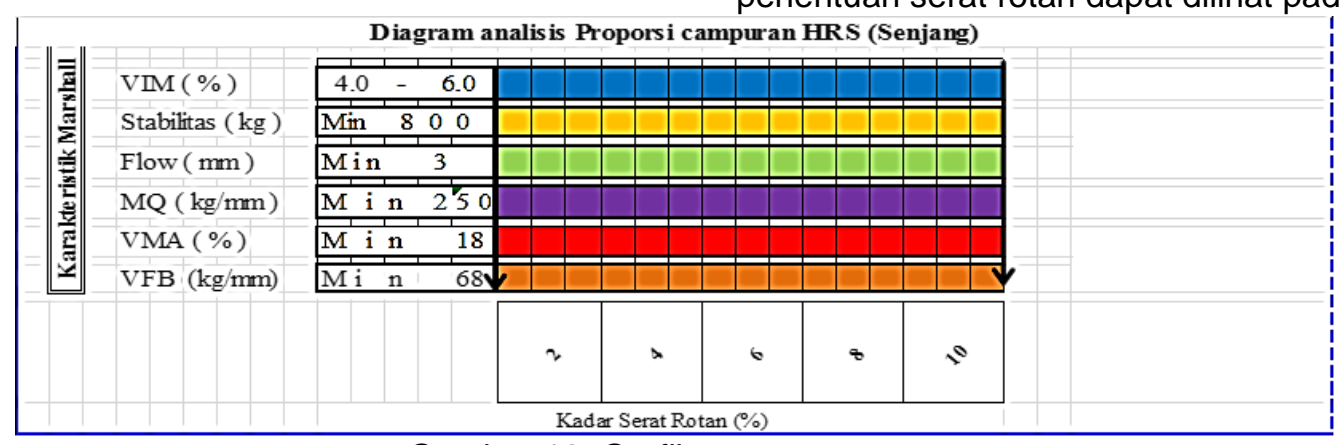

Gambar 12. Grafik penentuan serat rotan

\section{Durabilitas untuk HRS-WC}

Dari hasil pengujian Marshall Immersion diperoleh nilai rata-rata untuk indeks perendaman yaitu 94,77 $\%$. Berdasarkan nilai tersebut dapat disimpulkan bahwa perkerasan jalan yang menggunakan Serat Rotan sebagai bahan tambah untuk Lataston HRSWC tahan terhadap suhu dan perendaman air.

\section{Penentuan serat rotan Lataston HRS-BASE}

Penentuan proporsi serat rotan dapat ditentukan serat rotan dalam campuran Lataston HRS-BASE yaitu serat rotan yang memenuhi semua kriteria atau karakteristik marshall campuran mulai dari proporsi serat rotan $0 \%$ - $10 \%$ untuk lataston HRS-BASE. Untuk penentuan nilai optimum untuk marshall immersion, serat rotan yang digunakan yaitu $10 \%$. Karena menggunakan serat rotan terbanyak, juga dengan stabilitas paing kecil sehingga jika campuran masih tahan terhadap perendaman, apalagi campuran lainnya yang stabilitasnya besar. Grafik penentuan serat rotan Lataston HRS-BASE disajikan pada Gambar 13. 


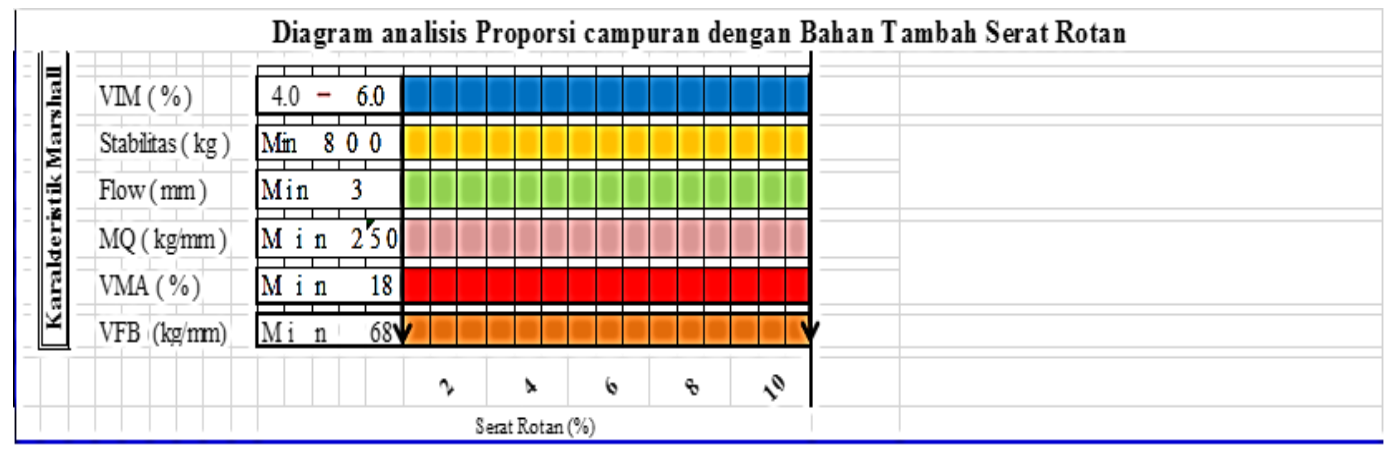

Gambar 13. Grafik penentuan serat rotan Lataston HRS-BASE

\section{Durabilitas untuk HRS-BASE}

Dari hasil pengujian Marshall Immersion diperoleh nilai rata-rata untuk indeks perendaman yaitu 92,48 $\%$. Berdasarkan nilai tersebut dapat disimpulkan bahwa perkerasan jalan yang menggunakan Serat Rotan sebagai bahan tambah untuk Lataston HRSBASE tahan terhadap suhu dan perendaman air.

\section{KESIMPULAN}

Pengaruh penggunaan serat rotan dalam campuran lataston HRS-WC dan HRS-BASE adalah Stabilitas meningkat, VIM meningkat, flow meningkat, VMA meningkat, dan VFB menurun. durabilitas/Indeks kekuatan Sisa/Indeks perendaman campuran masih memenuhi standar/spesifikasi yang di tetapkan bina marga yaitu campuran tahan terhadap suhu dan lamanya terendam dalam air.

\section{DAFTAR PUSTAKA}

[1] "Spesifikasi Umum Bina Marga Divisi 62010 Perk Eras An Aspal." [Online]. Available: https://www.scribd.com/doc/52889551/Spesifikas i-Umum-Bina-Marga-Divisi-6-2010-Perk-ErasAn-Aspal.
[2] I. Basuki, "Pengaruh Serat Serabut Kelapa Sebagai Bahan Tambah dengan Filler Serbuk Bentonit Pada HRS-Base Dan HRS-WC," vol. 7, no. 3, p. 17, 2007.

[3] S. N. Permana, D. Prasetyanto, and R. Zurni, "Studi Penggunaan Limbah Las Karbit Untuk Bahan Tambah Pada Perkerasan Laston Gradasi AC-WC," p. 10.

[4] A. Kholiq and T. Hidayatullah, "Penggunaan Bahan Additive Wetfix-Be Sebagai Bahan Tambahan Pada Lapis Permukaan AC-WC," vol. 5, no. 2, p. 17, 2017.

[5] "Penggunaan Abu Batubara Hasil Pembakaran Asphalt Mixing Plant (Amp) Sebagai Bahan Campuran Lapis Aspal Beton (Laston) | Adi | Jurnal Teknologi Mineral dan Batubara." [Online]. Available:

https://jurnal.tekmira.esdm.go.id/index.php/miner ba/article/view/144. [Accessed: 09-Dec-2019].

[6] D. Oleh, "(Menggunakan Aspal Retona Blend 55)," p. 61.

[7] "Pengaruh Bahan Tambah Limbah Logam Cor Pada Asphalt Concrete-Wearing Course (ACWC) Terhadap Karakteristik Marshall The Effect Of Additional Materials Of Cast Metal Waste In Asphalt Concrete-Wearing Course (AC-WC) On Marshall Characteristics - UTY Open Access." [Online]. Available: http://eprints.uty.ac.id/3191/. 